\title{
FAMILIAL VITAMIN D-RESISTANT RICKETS
}

\author{
METABOLIC STUDIES IN ONE FAMILY CONCERNING AETIOLOGY AND \\ TREATMENT, AND INDICATING THE SEPARATE ACTIONS OF VITAMIN D \\ BY
}

\author{
C. P. DANCASTER * and W. P. U. JACKSON
}

From the Endocrine Group, Department of Medicine, Groote Schuur Hospital and University of Cape Town, South Africa

(RECEIVED FOR PUBLICATION FEBRUARY 2, 1959)

Rickets which is refractory to ordinary doses of vitamin $D$ was first recognized when vitamin preparations of high potency became available (Albright, Butler and Bloomberg, 1937). As an isolated metabolic disorder it is commonly known as 'vitamin D-resistant rickets', also as 'phosphate diabetes' (Fanconi, 1936a, b) and phosphate losing(or renal tubular) rickets, type 1 (Dent, 1952). Whereas it was originally regarded as a rare conditionFreeman and Dunsky (1950) found only some 30 cases in the literature up to 1950 -Dent and Harris (1956) consider it the most common form of rickets in England at present. Possible explanations of its apparent increase are the diminished incidence of ordinary rickets in England following fortification of various foodstuffs with vitamin $D$, and an awareness of the family trait and the possible association of renal dysfunction with the resistant type.

Vitamin D-resistant rickets in many ways resembles true rickets (e.g. the changes in blood chemistry and histological appearance). However, there are differences between these conditions. The resistant type is familial (in the large family described by Winters, Graham, Williams, McFalls and Burnett (1958), it appeared as a sex-linked dominant characteristic), the serum calcium is never low enough to cause tetany, the level of urine cakcium in some is normal and the muscular weakness and hypotonia, so typical in classical rickets, is not very conspicuous. In addition, the patients usually appear well nourished and generally healthy. Very large doses of vitamin D or dihydrotachysterol (AT 10) are necessary to initiate mineralization. Furthermore, radiographs may show very little rachitic change at the bone ends, despite pronounced dwarfing and typical biochemistry. There is no excess aminoaciduria.

\footnotetext{
- Senior Bursar, Council for Scientific and Industrial Research.
}

The aetiology of the condition is not fully understood. It is not a dietary deficiency of any known factor, nor is it due to lack of intestinal absorption of vitamin $D$, since intravenous vitamin $D$ fails to evoke a response, and blood levels of vitamin $D$ have been normal (Freeman and Dunsky, 1950). A defect in renal function with resultant hyperphosphaturia has been suggested by Fanconi (1936a, b), Robertson, Harris and McCune (1942), Dent (1952) and Jackson and Linder (1953). This hypothesis has much to commend it. Familial defects in renal tubular function associated with bony abnormalities of rachitic and osteomalacic type are recognized syndromes. Diminished tubular reabsorption can affect numerous substances and produce various clinical pictures. It is postulated that phosphorus reabsorption alone may be affected, resulting in a clinical condition resembling rickets but resistant to ordinary doses of vitamin D. It has been shown that in cases of Fanconi's syndrome (in which there is deficient tubular reabsorption of phosphorus, glucose, amino-acids, water and potassium) large doses of vitamin $D$, in addition to correcting skeletal deformities and phosphorus excretion, can improve tubular reabsorption of other substances, so that diminished glycosuria and amino-aciduria result. In vitamin D-resistant rickets, renal tubular reabsorption of phosphorus has also improved after very large doses of vitamin D. Dent (1952) has reported two brothers with the disease, one of whom had renal glycosuria while the other did not.

However, Albright et al. (1937) believed that there was an intrinsic resistance to the primary effect of vitamin D. According to their view, deficient absorption of calcium from the gastro-intestinal canal resulted in a low serum calcium and this caused parathyroid hyperplasia. Increased parathyroid secretion led to hyperphosphaturia and a lowering of the serum phosphorus. Any effects from 
vitamin $D$ therapy were interpreted as being due to reduction of the parathyroid hypersecretion as the absorption of calcium became normal.

\section{Case Histories}

A family of bow-legged children (Fig. 1) presented at the out-patient department. There were four children, three males aged 7,9 and 11 years and one female aged 3 years. All were dwarfed but well nourished. As can be seen (Table 1) the dwarfing is mainly accounted for by the lack of growth of the lower segment. They had all been exposed to a great deal of sunlight and two of them (James and Elizabeth) had had 1 drachm of Vidaylin ( $=800$ units vitamin D) daily for two months before being seen by us. Skeletal changes, which were strikingly similar in each, had first been noticed when they started to walk. There was anterior and lateral bowing of the tibiae and femora. The skull was normal and no protuberance could be felt in the ribs and wrists. There were no other abnormal findings clinically. The mother of these children had had an osteotomy at the age of 13, because of bowed legs, and the residual deformity was still apparent. We were unable to establish any other family history.

TABLE 1

MEASUREMENTS AND WEIGHTS OF FAMILY

\begin{tabular}{|c|c|c|c|c|c|c|c|}
\hline & & Height (in.) & Weight (lb.) & Span (in.) & Lower Segment & Upper Segment & Age (years) \\
\hline $\begin{array}{l}\text { James } \\
\text { Henry } \\
\text { Peter } \\
\text { Elizabeth }\end{array}$ & $\begin{array}{l}\cdots \\
\cdots \\
\cdots\end{array}$ & $\begin{array}{ll}46 & (54)^{*} \\
45 & (51) \\
44 & (47 \cdot 2) \\
33 \frac{1}{2}(37)\end{array}$ & $\begin{array}{l}62(67) \\
55(58) \\
44(48) \\
30(32)\end{array}$ & $\begin{array}{ll}49 & (53 \cdot 4) \\
48 \frac{1}{2}(51) & \\
46 & (46) \\
33 \frac{1}{2} & (36)\end{array}$ & $\begin{array}{l}21 \frac{1}{2}(27) \\
21 \frac{1}{2}(25) \\
20(22 \cdot 5) \\
15 \frac{1}{2}(16)\end{array}$ & $\begin{array}{ll}25 \frac{1}{2} & (27) \\
24 \frac{1}{4} & (26) \\
24 & \left(24 \frac{8}{4}\right) \\
18 & (21)\end{array}$ & $\begin{array}{r}10 \\
9 \\
7 \\
3\end{array}$ \\
\hline Mother & $\cdots$ & 62 & $136 q$ & $65 t$ & $31 \frac{1}{2}$ & $30 \frac{1}{2}$ & 38 \\
\hline
\end{tabular}

* Normal figures in brackets. (Adapted from Engelbach, Endocrine Medicine, Springfield, Illinois. Charles C. Thomas, 1932.)

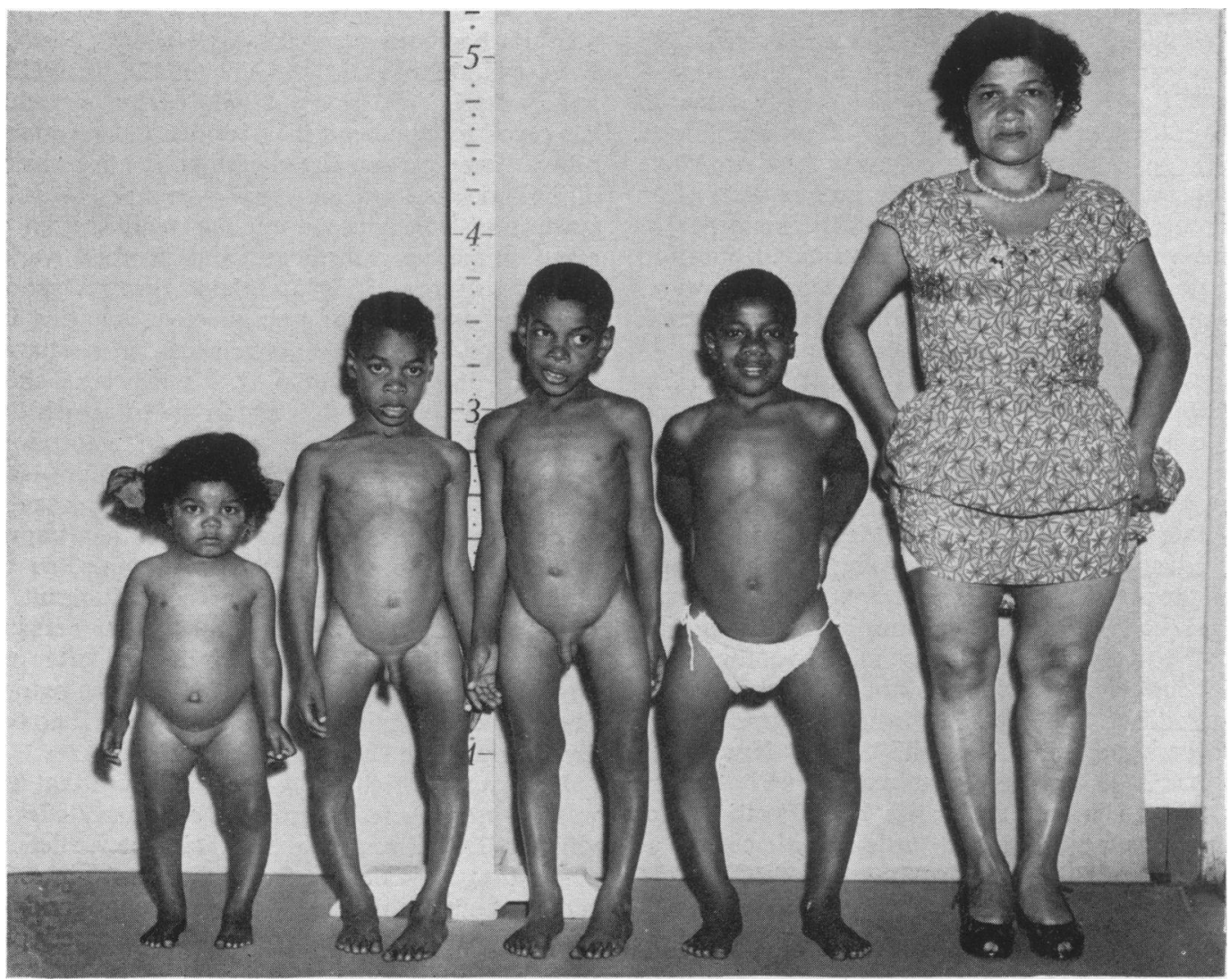

Fig. 1.-Family showing vitamin D-resistant rickets. 
Radiography. The bowing of the tibiae and femora is common to all four children. Only Elizabeth, the youngest, had typically rachitic epiphyseal changes present at the wrist. In the others the most marked changes occurred in the tibial epiphyses (Fig. 2). A lack of calcification particularly affecting the medial half of the epiphyses is characteristic of vitamin D-resistant rickets (Dent, 1958). This is well seen in Elizabeth with subsequent calcification after therapy (Fig. 2c, d). There was no radiological evidence of secondary hyperparathyroidism.

Initial Laboratory Investigations. Biochemical examination revealed low serum inorganic phosphorus, raised alkaline phosphatase and normal (or slightly reduced) serum calcium figures (Table 2). Other electrolytes were normal. James' serum phosphorus readings ranged from 2.0 to $4.5 \mathrm{mg}$. per $100 \mathrm{ml}$. (11 estimations). Potassium was $3.6 \mathrm{mEq} . / \mathrm{l}$., sodium $150 \mathrm{mEq} . / 1$., chloride $106 \mathrm{mEq}$. $/ 1$. and blood urea $26 \mathrm{mg}$. per $100 \mathrm{ml}$. His blood count was normal except that there was an unexplained eosinophilia of $20 \%$.

TABLE 2

BIOCHEMICAL INVESTIGATIONS

\begin{tabular}{|c|c|c|c|}
\hline & $\begin{array}{l}\text { Cakcium } \\
\text { (mg-/100 ml.) }\end{array}$ & $\begin{array}{c}\text { Inorganic Phosphorus } \\
\text { (mg./100 ml.) }\end{array}$ & $\begin{array}{c}\text { Alkaline } \\
\text { Phosphatase* }\end{array}$ \\
\hline $\begin{array}{l}\text { Henry . } \\
\text { Elizabeth } \\
\text { Peter .. } \\
\text { James . } \\
\text { Mother . }\end{array}$ & $\begin{array}{l}9 \cdot 1 \\
9 \cdot 6 \\
9 \cdot 4 \\
9 \cdot 4\end{array}$ & $\begin{array}{l}2 \cdot 6 \\
1 \cdot 8 \\
2 \cdot 2 \\
2 \cdot 1 \\
2 \cdot 7\end{array}$ & $\begin{array}{r}22 \cdot 5 \\
34 \cdot 6 \\
22 \cdot 5 \\
41 \cdot 6 \\
6 \cdot 5\end{array}$ \\
\hline
\end{tabular}

- Shinowara-Bodansky

The findings thus far indicated that we were dealing with a type of familial rickets. There was no glycosuria, polyuria or amino-aciduria, but the amount of phosphorus excreted in the $\mathbf{2 4}$ hours was high in relation to the serum level, and there was a diminished tubular reabsorption of phosphorus (Table 3).

It was decided to employ large doses of vitamin D after control studies and metabolic balances had been performed on two of the children, Elizabeth and James.
In addition, the effect of parathormone was observed (Ellsworth-Howard test) and renal function was investigated (creatinine clearance studies).

\section{Methods}

Response to Vitamin D using Metabolic Balance Studies. Eight consecutive five-day metabolic balance studies were performed on James while he was receiving a normal diet. The dose of vitamin D was gradually increased during this time up to a maximum of 1 million units daily (supplied as Ostelin Forte, 50,000 units per tablet by Glaxo.)

Three consecutive five-day metabolic balance studies were performed on Elizabeth, one a control and the others during the administration of large doses of vitamin D $(400,000$ and 1 million units daily).

Food and stools were homogenized and these and the urine were analysed for calcium, phosphorus, nitrogen and potassium content. Faecal collections ran from mid-day to mid-day and stool markers were not used. Food and urine collections went from 7 a.m. to 7 a.m. Bowels were kept regular by bland non-metabolic laxatives when necessary. Results are shown in Figs. 3 and 5, charted after the manner of Reifenstein, Albright and Wells (1945). Serum levels of calcium, phosphorus and alkaline phosphatase were taken at frequent intervals in order to detect any effect of vitamin D, either therapeutic or toxic, and to correlate any variation in the blood with other metabolic changes.

Ellsworth-Howard Test. Parathyroid hormone in the dosage of 200 U.S.P. was injected intravenously after three control periods of one hour each. The urine was collected by catheter and the phosphorus content estimated in three periods before and for three similar periods after injection.

Creatinine Clearance Studies. The 24-hour urinary excretion of creatinine and phosphorus were calculated and the serum level of these substances was estimated during this collection. From these figures the percentage of phosphorus reabsorbed by the tubules was calculated.



(a)

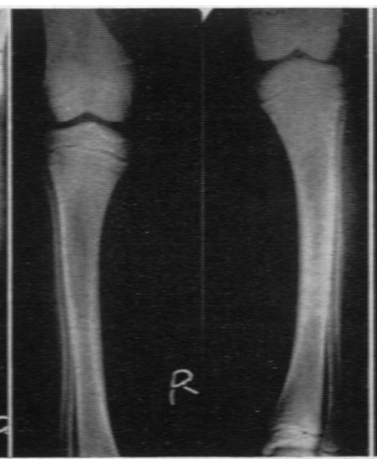

(b)

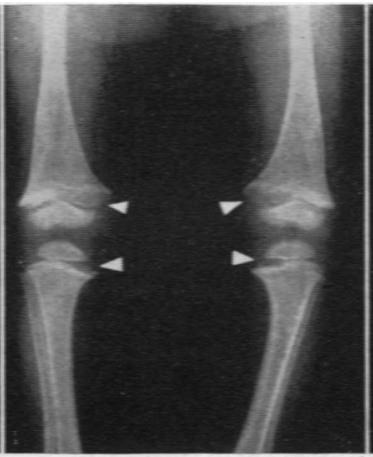

(c)

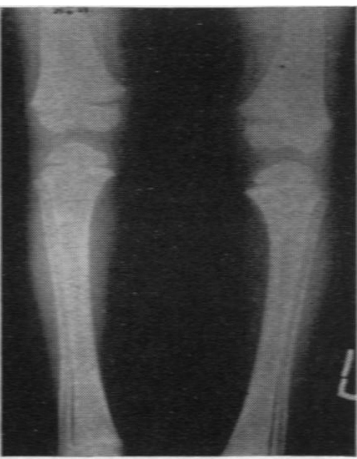

(d)

Fig. 2.-(a) James' radiograph showing (1) lack of cakcification particularly of medial aspect of growing bone at upper end of tibiae (arrows); (2) obliquity of epiphyses; (3) Harris' lines at upper and lower tibia. (b) James: healing four months later. (c) Elizabeth: radiograph showing lack of calcification particularly of medial aspect of growing bone at upper tibial and lower femoral epiphyses (arrows). d) Elizabeth: healing four months later. 
TABLE 3

RENAL FUNCTION STUDIES

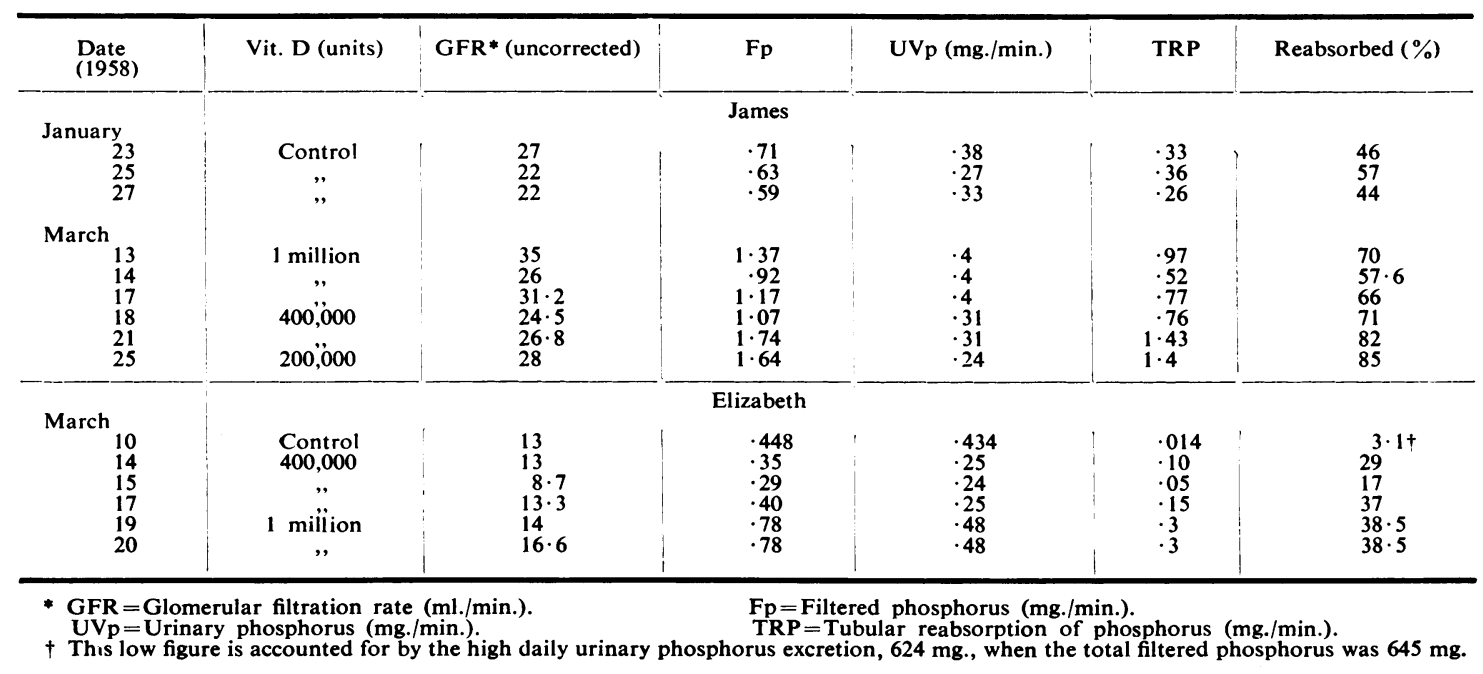

\section{Results}

Renal Function Studies. The 24-hour creatinine clearance was estimated in two patients (Elizabeth and James) before and during therapy with vitamin $\mathrm{D}$, to observe whether there was a diminished tubular reabsorption of phosphorus and whether this would be corrected by treatment. In both cases there was an improvement in tubular reabsorption of phosphorus after therapy. Results are shown in Table 3. There was possibly a slight increase in glomerular filtration rate.

Response to Parathyroid Extract (Parathormone, Lilly). In view of the alleged tubular defect in this condition and the possible secondary hyperparathyroidism, the response to parathyroid extract was investigated (Table 4). There was a poor phosphorus diuresis after the intravenous administration of 200 I.U. parathormone. However, the interpretation of this finding is obscure since we have found that not all normal subjects respond to intravenous parathormone (Dancaster, Schendel and Jackson. 1959).

\section{Metabolic Balance Studies}

James(Figs. 3 and 4). Calcium Metabolism. The difference between the faecal excretion of calcium in period 1 and periods 2 and 3 is probably due to incomplete collection in period 1. For this reason an average of the faecal excretions over the first three periods is considered more accurate. The gastro-intestinal absorption was poor during this time, resulting in a negative balance. The dose of calciferol was increased to 100,000 units but this had no effect on faecal excretion of calcium. However, an increase to 400,000 units daily in period 5 , and to 1 million units daily in period 6 improved gastro-intestinal absorption. Again, an
TABLE 4

ELLSWORTH-HOWARD TEST: MARCH 30, 1958

\begin{tabular}{|c|c|c|}
\hline & $\begin{array}{c}\text { Urinary Phosphorus } \\
\text { (mg./hr.) }\end{array}$ & $\begin{array}{c}\text { Serum Phosphorus } \\
\text { (mg. \%) }\end{array}$ \\
\hline $\begin{array}{rr}\text { Specimen } & 1 \\
2 \\
3\end{array}$ & $\begin{array}{l}9 \cdot 43 \\
29 \cdot 39-A v .16 \cdot 5 \\
10 \cdot 63\end{array}$ & Period $2: 2 \cdot 63$ \\
\hline $\begin{array}{r}\text { Parathormon } \\
\text { Specimen } 4 \\
5 \\
6\end{array}$ & $\begin{array}{l}00 \text { units intravenous } \\
34 \cdot 90 \\
13 \cdot 11-\text { Av. } 24 \cdot 3 \\
24 \cdot 98\end{array}$ & Period 5: $2 \cdot 50$ \\
\hline
\end{tabular}

average of faecal excretions in periods 5 and 6 is probably more accurate than their separate representations. In spite of improved absorption the patient remained in negative balance during this time, and it was only after a month that the gastro-intestinal absorption improved sufficiently to produce a positive balance (periods 7 and 8).

In agreement with earlier workers we found the urinary excretion of calcium to be low (10-25 mg./day), in spite of normal and even high serum figures. Calciferol administered in doses of 100,000 and 400,000 units daily had no effect on the urinary excretion and it was not until calciferol administration was increased to 1 million units daily that urinary calcium rose to abnormal figures (800 mg. daily in period 6). This extraordinary rise in urinary calcium preceded any marked improvement in gastro-intestinal absorption. The serum level exceeded $11 \mathrm{mg}$. per $100 \mathrm{ml}$. in period 5 and remained elevated till the end of the balance study. On account of this, calciferol administration was temporarily discontinued after period 8. The rise in serum calcium preceded any marked improvement in gastro-intestinal absorption and did not alter the very low urinary excretion of calcium in period 5 . 

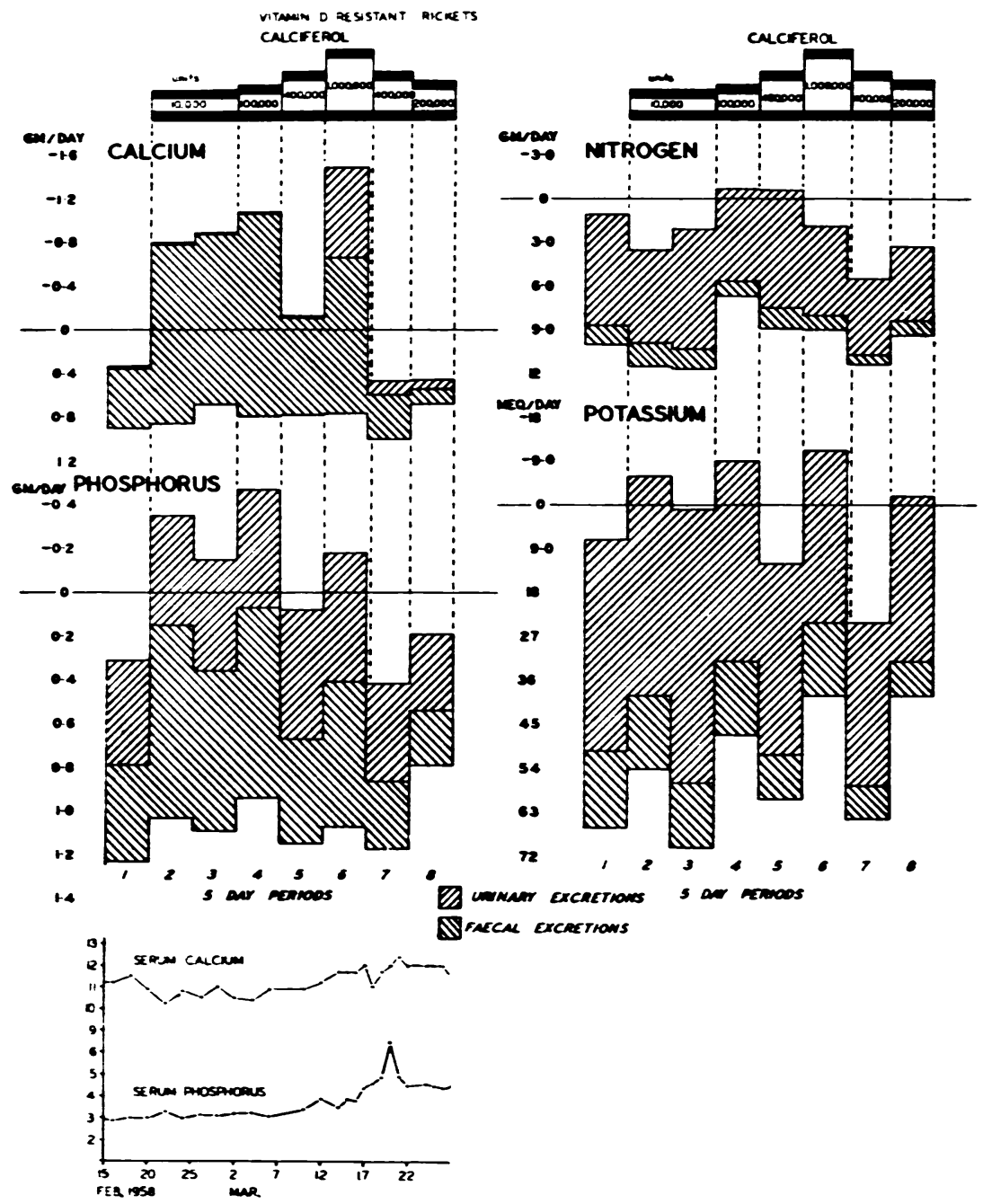

FiG. 3.-James: metabolic balance.

Phosphorus Metabolsm. An average of the faecal phosphorus over the first three periods indicated a very slight negative phosphorus balance at this time.

An increased dose of calciferol resulted in improvement in gastro-intestinal absorption comparable to that achieved with calcium. A definite positive balance was observed only in the final two periods but improvement in absorption was first evident in period 5 , while the patient was taking 400,000 units of cakiferol. The urinary excretion of phosphorus remained constant during the first six periods in spite of increasing serum figures. There was a small decrease in urinary phosphorus in periods 7 and 8.

Before therapy was commenced, serum phosphorus was estimated on 11 occasions and was usually between 2-3 mg. per $100 \mathrm{ml}$. However, it was twice above
$3 \mathrm{mg}$. per $100 \mathrm{ml}$. (3.9 and $4.5 \mathrm{mg}$. per $100 \mathrm{ml}$.). The daily variations in serum phosphorus level are noteworthy and are not unusual in this condition.

During therapy the serum phosphorus remained at about $3 \mathrm{mg}$. till period 6 , when, on 1 million units of calciferol, it started to rise.

Elizabeth (Figs. 5 and 6). The discrepancy in the faecal excretion of calcium and phosphorus between the first two balance periods may have been due to incomplete faecal collections in period 1. After calciferol administration had been increased to 1 million units daily (period 3) the gastro-intestinal absorption of calcium improved. Increased urinary excretion occurred during the same period.

A marked improvement in gastro-intestinal absorption 




of phosphorus occurred in period 3. Both the serum calcium and phosphorus were elevated at this time.

Nitrogen balances did not vary much, being mostly positive in both children. The faecal potassium seemed to fall in the latter periods of both children on vitamin D therapy (as was noticed by Henneman, Dempsey, Carroll and Albright, 1956, in sarcoidosis).

\section{Discussion}

Actions of Vitamin D. We believe that vitamin D has three main actions on calcium metabolism (discussed in greater detail elsewhere) (Jackson and Dancaster, 1959): (1) increasing absorption of calcium from the intestinal tract (Albright and Reifenstein, 1948); (2) increasing the serum calcium, presumably by drawing calcium from the bone and so tending to lead to decalcification (Dent, 1954); (3) increasing the urinary calcium by diminution in renal tubular reabsorption or possibly change in the form of the serum calcium. This is often the earliest action of all (Dent, 1954; Howard and Connor, 1954 ; Jackson, Hoffenberg, Linder and Irwin, 1956; Litvak, Moldawer, Forbes and Henneman, 1958).

These actions may appear separately or in different order in different patients. Thus we have seen the serum calcium rise without change in urinary calcium or intestinal absorption in patients with sarcoidosis given vitamin D. Dent has actually found a large fall in urine calcium in one case of osteomalacia under treatment while the serum calcium rose. We have seen the urine calcium rise without or before change in faecal or serum calcium in normal and in hypoparathyroid subjects.

The separate effects of vitamin D stand out clearly from the balance studies of James. The serum, and particularly the urinary calcium, rose markedly in period 6 without any change in intestinal absorption: the serum calcium then rose further while the urinary calcium fell vastly (periods 7 and 8 ). In the case of Elizabeth, the serum cakcium appeared to rise before there was any fall in faecal calcium or a rise in urinary calcium, but this is less clear-cut.

In both children the initial urinary calcium was excedingly low ( 7 and $25 \mathrm{mg}$./day) despite a normal or even high-normal serum calcium. This presumably indicates a specific depression of renal excretory mechanism for calcium (? increased tubular reabsorption), possibly a part of the 'resistance' to the action of normal amounts of circulating vitamin $D$. In ordinary D-lack rickets, one frequently finds the same thing; i.e. an almost absent urinary calcium, with normal serum levels, further supporting the view that vitamin $\mathbf{D}$ has a specific action in maintaining the urinary excretion of calcium.

Mechanisms in Resistant Rickets and Its Treatment with Vitamin D. Pre-treatment balance studies, especially in James, indicate defective absorption of 
both calcium and phosphorus from the gut. In both children large doses of vitamin D (period 7 in James and period 3 in Elizabeth) plainly increased the intestinal absorption of both elements. In James we also have evidence of a distinct increase in phosphorus reabsorption by the renal tubules under the same treatment.

The mechanism of improved tubular reabsorption of phosphorus by vitamin $D$ is not certain. Albright has shown that patients with idiopathic hypoparathyroidism have an increased renal excretion of phosphorus after vitamin $D$, but if the parathyroids are intact the tubular reabsorption may be improved and the urine phosphorus may fall (Albright and Reifenstein, 1948). He interprets this as being due to secondary hypoparathyroidism following increase in serum calcium. In James the increase in serum calcium occurred on the same day as the improved tubular reabsorption, but in Elizabeth serum calcium elevation preceded any change in phosphorus reabsorption by four days. However, as the serum ca'cium did not remain consistently elevated during this time we do not consider this is evidence in favour of Albright's hypothesis. It may be that vitamin $D$ really increases tubular reabsorption of phosphorus by direct action on the kidneys in the resistant rickets syndrome.

As we found in a patient with adolescent osteomalacia with raised resistance to vitamin $D$, there appears to be evidence, at least in some cases, that both defective absorption of calcium from the gut and a 'phosphate leak' into the urine may be implicated in the aetiology of 'resistant rickets' (Jackson, Dowdle and Linder, 1958).

\section{Subsequent Treatment and Control}

As the aetiology of this condition is not com-
VITANA D RESSTANT RLOETS
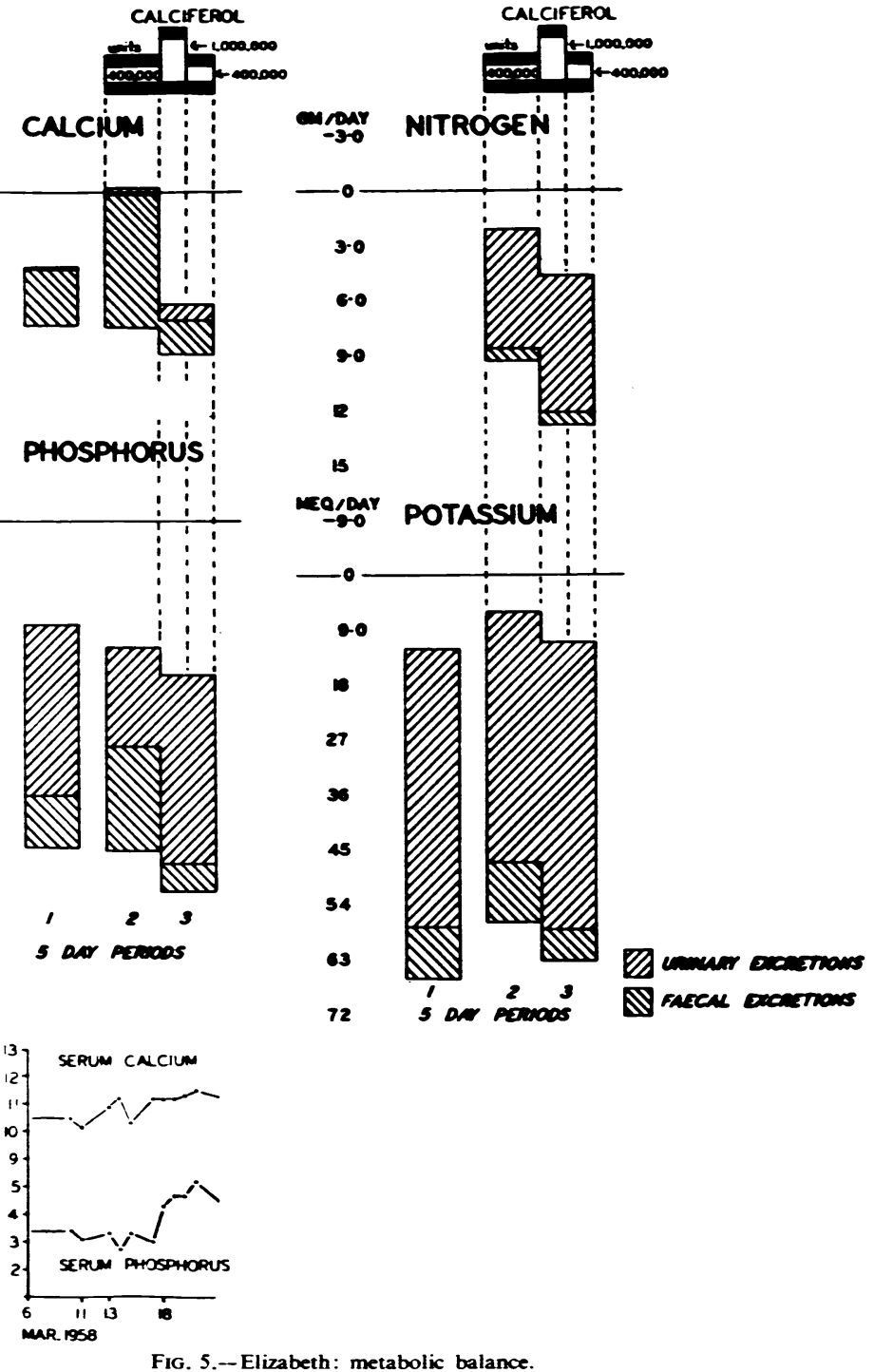

pletely understood, treatment must aim at correcting abnormal findings. With large doses of vitamin $\mathbf{D}$ the serum phosphorus and alkaline phosphatase may return to normal, as may the radiological appearances of the epiphyses. It is important to know to what extent treatment can prevent progression and aggravation of existing deformities and how best to assess cessation of activity of the rachitic process. While gross deformities of the shafts of long bones will have to be corrected surgically, the normal calcification of epiphyseal osteoid after 

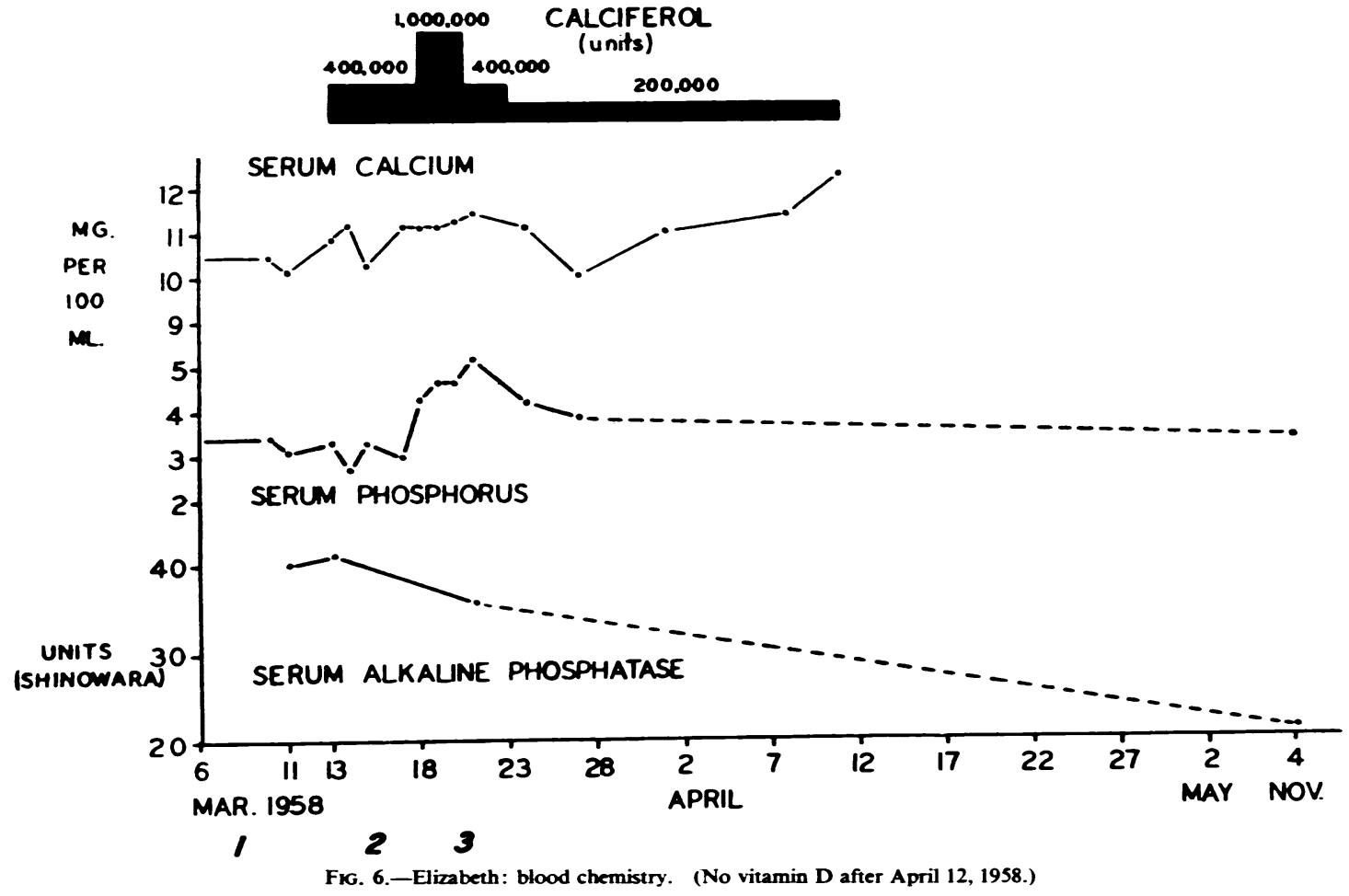

vitamin $\mathrm{D}$ prevents progression of the deformity and enables growth to occur (a patient has been reported as growing 12 inches in six years (Albright, Burnett, Parson, Reifenstein and Roos, 1946). Radiological control is probably the most satisfactory way of assessing progress because in some cases the abnormal changes in serum alkaline phosphatase and phosphorus may persist in spite of healing. In both our patients, the serum phosphorus returned to normal before there was any change in alkaline phosphatase, and there was radiological evidence of healing while the alkaline phosphatase was still elevated.

The length of time during which therapy has to be continued is often difficult to assess. Most cases heal spontaneously at puberty. However, even after radiological evidence of healing, relapses have occurred after puberty (Christiansson, 1958). The biochemical abnormalities may persist many years after epiphyseal closure. James has shown both radiological and biochemical healing after nine months therapy with large doses of vitamin D $(200,000$ units daily). However, after therapy had been discontinued for two months the alkaline phosphatase became elevated again (Fig. 4).
Although mineralization of the skeleton can be effected with vitamin $D$, there is still a lack of normal compact bone histologically (Engfeldt, Zetterström and Winberg, 1956). It would seem that vitamin D is not curative and that it is therefore extremely important to have regular radiological and biochemical assessment of progress. Any radiological evidence of regression would be an indication for further treatment, but whether complete biochemical cure (i.e. normal serum alkaline phosphatase and phosphorus) is essential, is debatable.

Although the therapeutic dose of vitamin $D$ is increased in this condition, the toxic threshold is apparently unaltered and the margin of safety therefore small. In fact some cases may be impossible to treat, since the curative dose from the point of view of the rickets may be toxic with regard to the serum calcium level.

If osteotomy is to be performed, it is usually done at puberty once the condition has been controlled with vitamin D. Discontinuance of therapy for a period of two weeks before surgery and during the period of bed rest has been advised in view of the possible complication of renal calculi. In James the serum calcium went up to $12.4 \mathrm{mg}$. per $100 \mathrm{ml}$. 
during treatment. By reducing the dose of vitamin D from 400,000 to 250,000 units daily the serum calcium level was reduced to $11 \cdot 5 \mathrm{mg}$. per $100 \mathrm{ml}$., but reduction of the dose of vitamin $D$ to 100,000 units daily had little effect in reducing the calcium further. However, four days after discontinuance of all vitamin $D$ therapy the serum calcium returned to normal at $10.0 \mathrm{mg}$. At one stage the blood urea rose from $31 \mathrm{mg}$. to $51 \mathrm{mg}$. while on vitamin $D$. There was hypercalcaemia $(11.6 \mathrm{mg} . / 100 \mathrm{ml}$.) and a hypercalcuria of $840 \mathrm{mg}$./day at this time. When the dose was reduced from 1 million to 400,000 units the blood urea fell to $26 \mathrm{mg}$. and the hypercalcuria diminished although the hypercalcaemia persisted.

In Elizabeth, although the serum calcium went above $12 \mathrm{mg}$. on one occasion and was frequently between 11-12 mg., the urinary calcium did not exceed $110 \mathrm{mg}$. per day. A reduction in dose of vitamin $\mathbf{D}$ had little effect on hypercalcaemia, but after its discontinuance the serum calcium returned to normal within four days.

From these findings it appears that routine testing of the urine with Sulkowitch's reagent is not sufficiently accurate in this condition. There were no clinical findings to suggest hypercalcaemia in our children despite serum levels above $12 \mathrm{mg}$. per $100 \mathrm{ml}$., so that periodic estimations of serum calcium are essential.

Note on Genetics. The appearance of 'resistant rickets' in a mother, three sons and one daughter is compatible with a dominant sex-linked inheritance, the responsible gene being situated on the nonhomologous portion of the $X$ chromosome. An affected father cannot pass on the condition to his sons, but the mother can pass it to both sons and daughters.

In the present family, of course, simple autosomal dominance would equally well fit, but sex-linked dominance seems more likely in this condition, judging from the work of Winters et al. (1958) and the data of Dent (1958).

\section{Summary}

A family of bow-legged children are described whose clinical features fitted the syndrome known as 'vitamin D-resistant rickets'. Metabolic balances and renal clearance studies were performed on two of them. An elevation of serum calcium and phos- phorus followed the use of vitamin $D$ in high dosage. This occurred in spite of continued poor gastro-intestinal absorption, which in one case persisted for $\mathbf{2 5}$ days after therapy was commenced and then improved.

It was considered that the source of the calcium which accounted for the hypercalcaemia and hypercalcuria on vitamin $\mathbf{D}$ was bone, but that the increase in serum phosphorus was accompanied by an improved renal tubular reabsorption. The three actions of vitamin $D$ on calcium metabolism appeared nicely separated in these patients. Their disorder seemed to be caused by a mixture of poor intestinal absorption of calcium and increased renal loss of phosphorus.

Our thanks are due to Professor F. Ford for enabling us to investigate Elizabeth, to Professor G. Linder and staff for alkaline phosphatase determinations, and to Professor F. Forman for constant interest and advice; also to Staff Nurse Schoonraad for his help in the metabolic ward. The work here reported is part of the programme of the Endocrine Research Group supported in the Department of Medicine, University of Cape Town, by the Council for Scientific and Industrial Research.

\section{REFERENCES}

Albright. F. and Reifenstein. E. C. (1948). The Parathyroid Glands and Metabolic Bone Diseases. Williams and Wilkins, Baltimore.

more. (1946). Medicine (Baltimore), 25. 399.

Butler, A. M. and Bloomberg. E. (1937). Amer. J. Dis. Child. 54. 529 .

Christiansson, G. (1958). Acta paediat. (Uppsala), 47, 288

Dancaster, C. P.. Schendel, H. and Jackson, W. P. U. (1959). In the

press. Clin. Sci.
Dent. C. E. (1952). J. Bone Jt Surg., 34B, 266.

(1954). In Ciba Foundation Symposium on the Kidney, p. 242 Churchill. London.

(1958). Personal communication.

and Harris. H. (1956). J. Bone Jt Surg.. 38B, 204.

Engelbach, W. (1932). Endocrine Medicine. Thomas. Springfield. III.

Engfeldt. B., Zetterstrōm, R. and Winberg. J. (1956). Ibid., 38A. 1323.

Fanconi. G. (1936). Quoted by McCune, D. J., Mason. H. H. and Clarke, H. T. (1943). Amer. J. Dis. Child., 65, 81. (1936a), H. T. (1943). Amer. J. Dis. Chid

- (1936a). Disch. med. Wschr., 62, 1169.

Freeman, S. and Dunsky, I. (1950). Ibid.. 79. 409.

Henneman. P. H., Dempsey, E. F.. Carroll, E. L. and Albright. F. (1956). J. clin. Invest.. 35. i229.

Howard. J. E. and Connor, T. B. (1954). Trans. Ass. Amer. Phycns, 67, 199 .

Jackson. W. P. U. and Dancaster, C. P. (1959). J. Clin. Endocr. 19, 658.

- Dowdle, E. and Linder. G. C. (1958). Brit. med. J., 1. 1269 Hoffenberg. R.. Linder, G. C. and Irwin, L. (1956). J. Clin. Endocr., 16, 1043.

- and Linder, G. C. (1953). Quart. J. Med., $22,133$.

Litvak, J., Moldawer, M. P., Forbes, A. P. anj Henneman. P. H. (1958). Ibid.. 18, 246.

Reifenstein, E. C., Albright, F. and Wells. S. L. (1945). Ibid . 5. 367 Robertson, B. R., Harris. R. C. and McCune. D. J. (1942). Amer. J. Dis. Child.. C4, 958 .

Winters. R. W.. Graham, J. B.. Williams. T. F., McFalls. V. W. and Burnett C. H. (1958). Medicine (Baltimore), 37, 97. 